\title{
PIZD'óSH: \\ Nikolai Gogol, Abner Doubleday, and the Russian Origins of American Baseball M. R. Axelrod
}

IT IS A LITTLE KNOWN FACT in the annals of baseball history, and one which most American sportswriters from Grantland Rice to Red Smith have intentionally dismissed, that Abner Doubleday owed the origins of modern baseball not to the English game of "rounders" or to "One Old Cat," which most everyone has assumed, but to a short story written by one of the grand masters of Russian prose, Nikolai Gogol.

As fate would have it, Doubleday, whose interest in sport was only surpassed by his interest in engineering and letters, was extremely fond of Russian writers, and it was a fondness that bordered on adulation. Not only had he read many of the good Russian poets like Derzhavin and Zhukovsky, not to mention the genius of Pushkin, but he much admired some of the early prose works of Krylov and Turgenev. But the author who fascinated Doubleday the most was Gogol, and the story that proved to be the impulse for the game was Huyóvina.

While a cadet at West Point in 1838, Doubleday discovered Huyóvina (trans. Foul Play, 1826), a spritely short story written in Gogol's early "realistic" period. Although it lacked the acerbic fabulousness of Gogol's more mature works, it exhibited the kind of literary efficacy that inspired writers like Turgenev, Gontcharov, and Dostoevsky.

The story deals with a day in the life of two youthful friends. There is a particular passage in the tale that had the greatest impact on Doubleday. Originally translated from Russian into French (by Turgenev), the language in which Doubleday had first read it, none of the story's content was lost in translation, and the following excerpt (my translation from the original Russian) is the same one that stimulated Doubleday's imagination.

It was a quiet summer afternoon. The sun had reached its peak and was making its slow and gentle descent to the horizon. Komiskiya Meadow was fresh with the 
scent of dogwoods and nasturtiums and the sounds of cardinals and orioles mixed in a profusion of harmonies that came from a nearby copse. In the Komiskiya Meadow, by the edge of the Lake Mishygun, two young men walked. Mikhaylo Mantlovich and Gruvin Alexandrovitch, each twenty years old, were both dressed in khaki knickerbockers, ruffled at the bottom, and blousey white shirts, the sleeves of which were puffed at the elbows and narrowed at the wrists. Mikhaylo Mantlovich wore white socks; Gruvin Alexandrovitch, red socks. They often came to Komiskiya to discuss things like German philosophy or Russian literature or the political rhetoric of Herzen and Belinsky or the romance of traveling to far-off yankee lands. Komiskiya Meadow was a peaceful place, one that lent itself to intimate conversation, and the two young men, often called "the twins" because of their intellectual similarities, found the meadow a respite from the agitation that was St. Petersburg.

As they talked, Mikhaylo Mantlovich would swipe at dandelions with a walking cane he fashioned from a branch of a nearby oak tree while Gruvin Alexandrovitch would toss smooth-faced stones into the nearby lake. On this particular occasion, though, their usual congenial dialogue became rather heated. Usually as docile as new-born cubs, the two became veritable tigers when the subject of poetry was broached.

"That's absolute nonsense!" said Mikhaylo Mantlovich. "Vassily Maysov's poetry is beyond that cheap sentimentalism of Lvov or Emin or NeledinskyMetetsky. As lyricists go he must certainly rank with Pushkin."

"Pushkin!" screamed Gruvin Alexandrovitch. "Only Sandoy Kufaksynov could possibly rank with Pushkin."

"I have nothing but the greatest respect for Sandoye Kufaksynov," said Mikhaylo Mantlovich, "I have even once met him at a party in Ebetsya Brucklyana, but you must admit for the melody of his line play and his ability to cover all meters equally, no one can measure up to Vassily Maysov."

"Come, come Mikhaylo Mantlovich, no one?" Gruvin Alexandrovitch asked with a smile.

"No one," answered Mikhaylo Mantlovich. "No one is as consistent in his play."

"Not even Petyr Rusinoff or Tifory Kobuleshov?"

"They are completely different poets!" screamed Mikhaylo Mantlovich, banging his cane to the ground. "It would be like comparing Buby Gybsonovitch with Teodor Vyliyamssov!"

Angered by Mikhaylo Mantlovich's comment about Buby Gybsonovitch and Teodor Vyliyamssov, the former of which was a comrade of his, Gruvin Alexan- 
drovitch, who was walking ahead of Mikhaylo Mantlovich, turned and hurled one of the stones straight at Mikhaylo Mantlovich. Instinctively, Mikhaylo Mantlovich stepped into the speeding stone and swung at it in an attempt to protect himself.

The stone cracked against the oak walking stick and flew straight back at Gruvin Alexandrovitch who dodged the hurtling stone and slid headfirst to the meadow as the rock sailed over his head and across the lake, finally landing in a thicket surrounded by a herd of grazing phillies. Gruvin Alexandrovitch slowly raised his head and looked up at Mikhaylo Mantlovich who, standing like a giant, appeared to be as shocked by the incident as Gruvin Alexandrovitch himself.

"Are you okay?" asked Mikhaylo Mantlovich, concerned.

"Fine. And you?" asked Gruvin Alexandrovitch, wiping dirt stains off his face that made him look like a pirate.

Mikhaylo Mantlovich nodded. "That was a close call," he said, his face reddened as an Indian.

"I did not mean to brush you back like that," said Gruvin Alexandrovitch. "I do not know what got into me."

"No harm, Gruvin Alexandrovitch," said Mikhaylo Mantlovich, smiling. "Luckily I swung at the right time and did not miss."

"Yes, it was quite athletic of you," said Gruvin Alexandrovitch, "quite brave too."

And after dusting themselves off, the two boys laughed heartily at the episode, walked down to the water's edge and watched the ripples from the lake splash languidly against the bedrock.

The passage had an enormous impact on the young Doubleday who recognized in those brief lines the seeds of what was to become the game of baseball. But he needed more. So, in an attempt to find out whether Gogol himself had any ideas about what he had written or whether the passage was merely serendipitous, Doubleday began a correspondence with the Russian writer. At the time, Doubleday was a lad of nineteen, while Gogol was twenty-eight and had already written such stories as Mirgorod, The Old World Landowners, Viy, Taras Bulba, and Arabesques, not to mention his satirical comedy The Inspector General. But Doubleday had a hunch that Gogol knew more than he was letting on, and, in a series of letters that continued until Gogol's death in 1852, Doubleday and Gogol actually collaborated on the rules and regulations of the game of baseball as we know them. 
The most important of their baseball letters were written between 1838 and 1842 but none of the correspondence is extant since Doubleday's letters were burned along with Gogol's manuscript of Dead Souls, Part II, and Gogol's letters were, at Doubleday's request, buried with him. However, thanks to a brilliant study of Gogol's notebooks researched by Johann Arschkriecher, Professor of Eclectic Literature at Indiana UniversityFrench Lick, and published in his work Doubleday to Gogol to Chance: The Literary Origins of Baseball (1986), ${ }^{1}$ we now know what contributions Gogol actually made to the game and why Doubleday probably wanted Gogol's letters buried with him.

What we know is that Doubleday began writing Gogol in January, 1838, specifically asking him about the "stick and stone" episode in Foul Play. Gogol responded by writing that the idea was not new in Russia and that the Ukrainian peasant boys played a game called "zasrát "glazá," the object of which was to hit a thrown, oven-baked chicken turd with a short paddle, run to a "pizd'ósh," or "base," and run back again before the paddleman could be hit by someone throwing the turd. Gogol said he merely modified the game, feeling his reading audience might be offended if he used, as he wrote, "something as coarse as a shit-ball" instead of a stone. Most scholars believed Gogol was merely being ironic with the youthful Doubleday, but the game of "zasrát glazá" actually did exist and was played, just as Gogol indicated, by Ukrainian peasants as early as $1728 .{ }^{2}$

With that in mind, Doubleday suggested that the two of them collaborate on creating a "new" game which Doubleday called "baseball." Always one for the challenge of curiosities, Gogol consented. In subsequent letters, both Gogol and Doubleday attempted to formulate rules about the game though, according to Arschkriecher's work, there were many disagreements. Gogol, as most scholars of his life and work know, was a bit eccentric, his eccentricity eventually yielding to hallucinations and madness by the time of his death at the age of forty-three. It was in that vein of eccentricity that Gogol made numerous suggestions, many of which Doubleday categorically discarded. Among those was the suggestion that pitchers be allowed to spit on the ball or use various articles like emery boards to scar the surface of the ball to, in Gogol's words, "allow the ball to seek its own projection." But Doubleday felt those suggestions were not in keeping with the American ideal of "fair play" and refused to incorporate them into the rules. 
But other ideas abound as well. References in Gogol's Confessions of an Author (1847) ${ }^{3}$ indicate that the shape of the field and number of bases were probably the most disagreed-upon subjects. For example, as to the shape of the field, Doubleday had insisted on a rectangular playing field with numerous bases at irregular distances, but Gogol was adamant about using a diamond with equidistant pizd'osh. One would think that with an engineering background Doubleday would have recognized the elegance in Gogol's choice of shapes, a selection that was not arbitrary but, according to Gogol, religious, as were the number of bases. Doubleday suggested six or seven bases and, of course, a rectangular field, but Gogol recommended four bases because four "represents the macrocosm which the microcosm naturally reproduces" and a diamond instead of a rectangle since the diamond "is a symbol of light and brilliance, of moral and intellectual knowledge." Actually, Doubleday had not even thought about the practical applications of such a layout, tied as he was into its purely theoretical applications. But Gogol insisted that a rectangular field with different distances between bases did not lend itself very well to the "physics of running." This disagreement lasted for several months before Gogol finally convinced Doubleday to try running around a rectangle with seven bases. After Doubleday tried running around his irregular rectangular field, then tried running around Gogol's diamond of four bases ninety feet apart, he was positively amazed to see the difference, which lends more than a bit of credence to the position that Doubleday did not select the distance just for the sake of paying tribute to his favorite writer, but because it made him appear to be a better engineer.

Likewise, the choice of ninety feet between bases and nine men on a team and nine innings in a game was not merely serendipitous. The reason for Gogol's belief in the diamond has been mentioned, but the allegiance to numbers like nine and three and four is a rather fascinating bit of arcana.

About the time Gogol and Doubleday began their correspondence, Gogol was becoming increasingly attracted to metaphysics, to spiritual zealotry, and was already exhibiting the early signs of a religious madness that would later drive him insane. In his Confessions Gogol wrote that on the evening he received a letter from Doubleday he had a vision, a mystical vision, in which the spirit of God visited him in the shape of the number nine. As Gogol wrote, "The spirit came upon me and whispered in a desultory way that all things in life aspire toward perfection, that ultimate per- 
fection resides within the curve and stem of the number nine, the all-butcomplete, all-but-perfect, number nine." Such a statement would, of course, account for the plenitude of nines in the game which Gogol once deemed was "invested with the spirit of the Lord." Out of that "vision" Gogol convinced the impressionable Doubleday that establishing nines would make the game "sacred," thereby "sanctifying the glory of His name." As for the number of strikes and balls, Gogol said three was the ideal number for it represented the "number of the deity" while four represented the "temporal and mundane." The total, seven, implied, for Gogol, like St. Augustine, a totality which seemed to embody the "perfection of man" and, therefore, the "perfection of the game." Doubleday, a religious fellow himself, found Gogol's suggestion blessed with a Christian virtuosity that could not be ignored and felt compelled to implement the master's suggestion.

The last mention Gogol makes of baseball was in an 1842 entry at which time he noted a recommendation to Doubleday that he try to organize a game between two teams "of equal strength and skill." In fact, such a game did not transpire until four years later when the Gotham Knickerbockers lost to the New York Nine 23-1. Unfortunately, after June, 1842, their correspondence dropped off dramatically due primarily to the fact that after Doubleday graduated in 1842 he fought in the Mexican War and Gogol was becoming increasingly consumed by his masterpiece, Dead Souls, and his withdrawal from society to devote himself to religious meditation.

According to Dr. Arschkriecher, the last letter written by Gogol to Doubleday was sent on 4 February 1852, only two weeks before Gogol died. In it, Gogol asked Doubleday for a "pizdabrátiya" (which in today's English would translate to "franchise"), if, in fact, the game became popular. Though there's no letter to record Doubleday's response to Gogol's request, a note in Gogol's notebook dated 21 February 1852, the last day of Gogol's life, had Doubleday's initials and the Russian phrase "zalúpa kónskaya" (which, simply translated, means "jerk") scribbled in the margins. Apparently, Doubleday denied his master's request for reasons that still remain a mystery.

When Doubleday died in 1893 there was no mention whatsoever of Gogol's contribution to the game, which may account for the fact that 
Gogol's letters went to Doubleday's grave. Nor has anyone ever really given Gogol the full measure of credit he deserved for contributing enormously to the creation of the great American sport as we know it. As a matter of fact, the only acknowledgment ever accorded Gogol for the contribution he made to baseball is a tiny plaque located at a country hostel in the Russian village of Dikanka. The sign reads in Russian:

Here is where Nikolai Gogol perfected pizd'osh, a game which became America's pastime.

Perhaps nothing more could have made him prouder.

\section{Notes}

1. Doubleday to Gogol to Chance: The Literary Origins of Baseball, Dr. Johann Arschkriecher; Indiana University Press; Bloomington, Indiana; 1986.

2. The History of Pizd'osh, Chud'esá V. Réshet'é; Oxford University Press, Oxford, England, 1983.

3. Confessions of an Author, translated and edited by Vysosat' Ispál'tsa; Cambridge University Press, Cambridge, England, 1978. 